Plant Tissue Cult. \& Biotech. 29(2): 257-266, 2019 (December)

CBangladesh Assoc. for Plant Tissue Culture \& Biotechnology

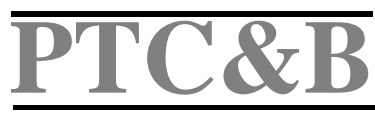

\title{
Dual Phase Regeneration System for Mass Propagation of Cymbidium aloifolium (L.) Sw.: A High Value Medicinal Orchid
}

\author{
Mohammad Musharof Hossain* and Madhu Sharma ${ }^{1}$ \\ Department of Botany, University of Chittagong, Chittagong-4331, Bangladesh \\ Key words: PLBs, Cymbidium, Somatic embryogenesis, Orchid, Liquid culture
}

\begin{abstract}
Efficient micropropagation protocol was established in Cymbidium aloifolium through induction of secondary $\left(2^{\circ}\right)$ protocorms from primary $\left(1^{\circ}\right)$ protocorms, shoot buds (SBs) and protocorm-like bodies (PLBs) from pseudo-stem segments of in vitro raised seedlings. Neo-formation of $2^{\circ}$ protocorms from $1^{\circ}$ protocorms was obtained in liquid and agar-solidified Phytamax (PM) medium with NAA, 2,4-D, BAP and Kn at different concentrations and combinations. The highest number of $2^{\circ}$ protocorms was induced in liquid PM medium (9.76 $\pm 0.88 / 1^{\circ}$ protocorm) amended with $2.0 \mathrm{mg} / \mathrm{BAP}+1.0 \mathrm{mg} / 2,4-$ D. Although protocorms proliferated profusely in liquid medium, hyperhydricity was observed after prolonged culture. Both SBs and PLBs were induced from pseudo-stem segments on agar gelled PM medium and the mode of differentiation was dependent upon specific PGRs concentrations. The maximum number of SBs (5.80 \pm 2.59 /explant) was recorded in BAP and NAA at $1.0 \mathrm{mg} / \mathrm{each}$, while the maximum number of PLBs $(7.20 \pm 3.22 /$ explant $)$ were induced in $2.0 \mathrm{mg} / \mathrm{BAP}$ and NAA each. Well developed root systems were induced SBs and PLBs on transferring to half-strength PM medium fortified with $0.5 \mathrm{mg} \Lambda$ IAA. The rooted plantlets were transferred to the greenhouse with $95 \%$ survival.
\end{abstract}

\section{Introduction}

Cymbidium aloifolium (L.) Sw., commonly known as 'aloe-leafed cymbidium', is a tropical tender perennial herb. This is an epiphytic orchid distributed in tropical and subtropical Asia. It is a high value medicinal plant use in the traditional system of medicine. Root powder is used to cure paralysis. Tribal people of Chittagong Hill Tracts (Bangladesh) use leaf extract for treating boils and fever (Hossain 2011). Pasted aerial roots are used for

*Author of correspondence. <musharof20bd@yahoo.com>. ${ }^{1}$ Division of Biotechnology, CSIRInstitute of Himalayan Bioresource Technology, Palampur-176 061, Himachal Pradesh, India.

DOI: https://doi.org/10.3329/ptcb.v29i2.44514 
joining fractured bones and whole plant is used as emetic, tonic and in treating ear-ache, burns and sores. Plant is pounded with ginger and the water extract is given to cure chronic illness, weakness of eyes, vertigo and paralysis (Hossain 2011). Apart from medicinal value it has high floricultural importance as this plant produces $20-30$ perpetual attractive flowers of a unique frosty texture on long pendulous inflorescence. Unfortunately, this orchid is disappearing at an alarming rate due to continuous destruction of natural habitats, over exploitation for medicinal purposes, killing of pollinators, climate change, unauthorized trade and ruthless collection by orchid lovers. The present status of this orchid undoubtedly led to an increased emphasis on mass propagation and conservation in nature.

In vitro seed germination of C. aloifolium and mass production of plantlets through in vitro culture of plant parts has been reported by several workers. Hossain et al. (2008) reported BAP induced high frequency PLBs production from the base of cultured seedlings but the regeneration ability of the seedlings was observed for first few weeks only. For commercial production of seedlings/plantlets for economic and conservation applications, a precise, simple, economical, rapidly multiplying and highly reproducible protocol is required. The major obstacles for mass propagation of economically important orchids, including C. aloifolium, are: (i) Selection of suitable explants for micropropagation and (ii) scaling up and automation of the techniques (Hossain et al. 2010).

The liquid culture systems have rarely been used in commercial laboratories for orchid tissue culture. Although the liquid culture system offers the advantages of rapid growth and propagation, and the opportunity of scaling-up and automation, it is more complicated to maintain, particularly when using sophisticated bio-reactors. Moreover, malformation or hyperhydricity (development of physiologically abnormal organ or proliferating bodies) is a common disadvantage of liquid culture system (Teisson and Alvard 1995) and a higher risk for contamination limits their use (Winkelmann et al. 2006). Dual phase culture system i.e., multiplication of PLBs in liquid medium and plantlet regeneration on agar solidified medium may reduce these barriers. Keeping in mind the above, present studies were undertaken in C. aloifolium for developing efficient protocols for: (a) induction of $2^{\circ}$ protocorms from $1^{\circ}$ protocorms; and (b) production of multiple shoot buds or PLBs from pseudo-stem segments. The multiple regeneration pathways developed for C. aloifolium could be employed for commercial production of seedlings of this high value medicinal orchid and could be extended to other orchids as well.

\section{Materials and Methods}

Six to seven month-old green capsules of Cymbidium aloifolium (L.) Sw. were collected from the naturally grown plants from the hilly forest of Cox's Bazar district of Bangladesh. The protocol followed for surface sterilization and inoculation of seeds was the same as described earlier (Hossain et al. 2009). The protocorms developed from 
cultured seeds were harvested after 7 - 8 weeks of germination and further use for regeneration experiments.

Liquid and agar gelled PM (PhytamaxTM, Cat. No. P-6793, Sigma, USA) supplemented with BAP (1.0 - $5.0 \mathrm{mg} /)$, Kn (1.0 - $2.0 \mathrm{mg} \Lambda)$, NAA (1.0 - $5.0 \mathrm{mg} /)$ and 2,4$\mathrm{D}(1.0-2.0 \mathrm{mg} /)$, either individually or in combinations were used. For culture of protocorms both liquid and agar-gelled media were used while only agar-solidified medium was used for culture of pseudo-stem segments harvested from in vitro raised seedlings. The $\mathrm{pH}$ of the medium was adjusted to 5.4 prior to autoclave at $121^{\circ} \mathrm{C}$ and at $15 \mathrm{psi}$ for $20 \mathrm{~min}$. Culture vessels were maintained in a culture room maintaining $14 \mathrm{hrs}$ photoperiod at $60 \mu \mathrm{mol} / \mathrm{m}^{2} / \mathrm{s}, 25 \pm 2{ }^{\circ} \mathrm{C}$ and $60 \% \mathrm{RH}$. Liquid cultures were kept on a platform shaker at $100 \mathrm{rpm}$ in the same culture conditions.

Fifty to 70 day-old seed-derived protocorms (average 200 per $150 \mathrm{ml}$ flask) were used for production of $2^{\circ}$ protocorms. Pseudo-stem segments $(0.5-1.0 \mathrm{~cm})$, were cut transversally from the base of the in vitro raised seedlings, and used for induction of PLBs or shoot buds. Five segments were cultured in each flask. Within two week of culture of both types of explants, $2^{\circ}$ protocorms (from $1^{\circ}$ protocorm), PLBs or SBs from pseudostem segments were produced. The average number of $2^{\circ}$ protocorms and SBs or PLBs developed per explant was calculated after one month of culture.

For induction of stout root system, the in vitro produced plantlets $(3-4 \mathrm{~cm})$ were grown individually in test tube containing $50 \mathrm{ml}$ of half and full strength agar solidified PM medium fortified with 0.5 or $1.0 \mathrm{mg} /$ IAA for 30 days. Well-rooted plantlets were taken out from culture tubes, washed thoroughly under running tap water to remove agar attached to the root surface and transferred to plastic pots $(15 \mathrm{~cm}$ dia. $\times 15 \mathrm{~cm}$ height) containing a potting mixture of sterile brick pieces, charcoal pieces, coco peat and vermiculite at $1: 1: 0.5: 0.5$ and kept in greenhouse $\left(25-30^{\circ} \mathrm{C}\right.$ and $\left.\mathrm{RH} 60-70 \%\right)$. Watering was done once in a day for the first one week and then twice in a week. Two hundred plantlets (derived from $100 \mathrm{SB}$ and $100 \mathrm{PLBs}$ ) were transferred to greenhouse and survival rate was recorded after two months of transfer to pots.

For histological studies, PLBs were fixed in formalin-acetic acid-alcohol (FAA) (1 ml formalin : $1 \mathrm{ml}$ acetic acid : $18 \mathrm{ml} 50 \%$ ethanol) solution for one week and preserved in $70 \%$ ethanol until use. Dehydration was done in tertiary butyl alcohol series. Infiltration was done with paraffin wax at $58-60^{\circ} \mathrm{C}$. Blocks were prepared using paraffin wax. Serial longitudinal sections $(12 \mu \mathrm{m})$ were cut with a microtome (Shandon Finsse ME, Thermo Electron Corp., UK). The staining procedure was the same as described by Prakash et al. (1999). The sections were observed under a light microscope (Labophot, Nikon Corp., Japan).

A complete randomized design (CRD) was used. The experiments were repeated thrice maintaining five replicates per treatment in micropropagation studies, while for rooting experiment, 10 shoots or PLB originated plantlets were used for each treatment. Mean values of these experiments were separated by ANOVA. Significance of the 
experiments was assessed by DMRT using STATISTICA data analysis software version 7 (Statsoft Wipro, USA) at a significant level $\mathrm{p}=0.05$.

\section{Results and Discussion}

An efficient and reproducible protocol was developed for mass propagation of $C$. aloifolium. Different pathways established for mass propagation were: (i) Production of $2^{\circ}$ protocorms from $1^{\circ}$ protocorms in both liquid and agar solidified culture, (ii) dual phase culture system i.e., protocorm multiplication in liquid medium and plantlet regeneration on agar-solidified medium, and (iii) induction of shoot buds and PLBs from pseudo-stem segments of in vitro raised seedlings. These morphogenetic pathways are described below.

The seeds produced green protocorms ( $1^{\circ}$ protocorms) on agar gelled PM medium (Fig. 1A,B) which were used for further regeneration studies. Neo-formation of $2^{\circ}$ protocorms from $1^{\circ}$ protocorms was found in both liquid and agar solidified PM medium supplemented with different concentrations and combinations of auxins (NAA and 2,4D) and cytokinins (BAP and $\mathrm{Kn}$ ) (Table 1). Initiation of $2^{\circ}$ protocorms occurred within two weeks of culture in liquid medium, whereas in agar solidified medium initiation started after three weeks of culture. The protocorms multiplied in liquid culture but failed to develop plantlets (Fig. $1 C_{1}, D_{1}, D_{2}$ ) unless transferred to agar solidified medium (Fig. 1D5, $\mathrm{D}_{6}$ ). Non-uniformity and hyperhydricity of $2^{\circ}$ protocorms was also observed in almost all the protocorms when these were kept for long durations ( $>3$ months) in the liquid medium (Fig. $\left.1 \mathrm{D}_{3}, \mathrm{D}_{4}\right)$. Significantly higher number of $2^{\circ}$ protocorms $\left(9.76 \pm 0.88 / 1^{\circ}\right.$ protocorm) were induced in liquid medium when fortified with $2.0 \mathrm{mg} / \mathrm{BAP}$ and 1.0 $\mathrm{mg} / 2,4-\mathrm{D}$, whereas in agar solidified medium highest number of $2^{\circ}$ protocorms $(7.00 \pm$ $4.04 / 1^{\circ}$ protocorm) was found in medium fortified with $1.0 \mathrm{mg} / \mathrm{Kn}$ and $1.0 \mathrm{mg} / 2,4-\mathrm{D}$. Percentage of protocorms that produced $2^{\circ}$ protocorms also varied in different concentrations and combinations of PGRs (Table 1). It was highest (97\%) in $2.0 \mathrm{mg} / \mathrm{BAP}$ $+1.0 \mathrm{mg} / 2,4-\mathrm{D}$ and in $1.0 \mathrm{mg} / \mathrm{Kn}+1.0 \mathrm{mg} / 2,4$-D. Initially the $1^{\circ}$ protocorms increased in length developing a rhizomatous structure and $2^{\circ}$ protocorms were regenerated in both liquid (Fig. $1 \mathrm{D}_{2}$ ) and agar gelled medium (Fig. $1 \mathrm{C}_{2}, \mathrm{C}_{3}, \mathrm{C}_{4}$ ). It is pertinent to mention here that, in agar solidified medium, the $1^{\circ}$ protocorms produced $2^{\circ}$ protocorms and subsequently developed into plantlets on the same medium (Fig. $1 C_{2}, C_{3}, C_{5}$ ). Based on the above findings, $2^{\circ}$ protocorms were produced in liquid medium and for mass scale production of plantlets these were transferred to agar gelled medium. PLBs were produced from the meristematic zones of the $1^{\circ}$ protocorms in C. aloifolium. Development of PLBs is considered to be a peculiarity which could be developed in two ways, i.e., direct (without intervening callus phase) and indirect (with an intermediary callus phase). The histological and cytological analyses of PLBs revealed the fact that these are equivalent to somatic embryos (Begum et al. 1994). PLBs could regenerate complete plantlets as these are somatic embryos. The cells of young PLBs are highly meristematic 
in nature and can be used to hasten and improve plant regeneration in Cymbidium (Teixeira da Silva et al. 2005).

Table 1. Production of $2^{\circ}$ protocorms (PLBs) from $1^{\circ}$ protocorms in Cymbidium aloifolium after 30 days of culture in ager gelled and liquid media.

\begin{tabular}{|c|c|c|c|c|c|c|c|}
\hline \multicolumn{4}{|c|}{ PGR (mg 1$)$} & \multicolumn{2}{|c|}{$\begin{array}{c}\text { Protocorms multiplication (\%) } \\
(\text { Mean } \pm \text { SE) })^{*}\end{array}$} & \multicolumn{2}{|c|}{$\begin{array}{c}\text { Production of } 2^{\circ} \text { protocorms / } \\
1^{\circ} \text { protocorm }(\text { Mean } \pm \mathrm{SE})^{*}\end{array}$} \\
\hline Cont. & & & & $23.12 \pm 0.95^{p}$ & $20.75 \pm 4.55^{\mathrm{f}}$ & $1.67 \pm 0.33^{1}$ & $1.00 \pm 0.54^{\mathrm{h}}$ \\
\hline 0.0 & 1.0 & - & - & $46.38 \pm 1.38^{1 \mathrm{~m}}$ & $50.20 \pm 3.34^{\mathrm{abcd}}$ & $2.67 \pm 0.88^{\mathrm{kl}}$ & $2.67 \pm 1.54^{g}$ \\
\hline 0.0 & 2.0 & - & - & $53.67 \pm 0.88^{\mathrm{ijk}}$ & $42.25 \pm 3.80^{\text {bcdef }}$ & $4.00 \pm 0.58^{\mathrm{ijk}}$ & $4.00 \pm 2.31^{\operatorname{defg}}$ \\
\hline 1.0 & 0.0 & - & - & $43.69 \pm 1.35^{\mathrm{lm}}$ & $51.72 \pm 4.24^{\mathrm{abcd}}$ & $4.00 \pm 0.58^{\mathrm{ijkl}}$ & $4.33 \pm 2.50^{\mathrm{defg}}$ \\
\hline 1.0 & 1.0 & - & - & $38.67 \pm 2.03^{\mathrm{mn}}$ & $50.32 \pm 7.50^{\mathrm{abcde}}$ & $4.33 \pm 0.33^{\mathrm{hijk}}$ & $3.33 \pm 1.92^{\mathrm{fg}}$ \\
\hline 1.0 & 2.0 & - & - & $30.33 \pm 2.40^{\mathrm{mop}}$ & $48.28 \pm 9.41^{\text {bcde }}$ & $3.00 \pm 0.58^{\mathrm{kl}}$ & $4.00 \pm 2.31^{\text {defg }}$ \\
\hline 2.0 & 0.0 & - & - & $33.23 \pm 2.29$ mop & $31.26 \pm 4.52^{\mathrm{cdef}}$ & $3.33 \pm 0.33^{\mathrm{kl}}$ & $3.33 \pm 1.92^{\mathrm{fg}}$ \\
\hline 2.0 & 1.0 & - & - & $37.33 \pm 1.86^{\mathrm{mno}}$ & $40.38 \pm 3.64^{\text {bcdef }}$ & $4.00 \pm 0.58^{\mathrm{ijk}}$ & $3.33 \pm 1.92^{\mathrm{fg}}$ \\
\hline 2.0 & 2.0 & - & - & $31.00 \pm 2.52^{\text {mop }}$ & $42.45 \pm 3.25^{\text {bcdef }}$ & $3.00 \pm 0.58^{\mathrm{kl}}$ & $5.33 \pm 3.08^{\text {abcde }}$ \\
\hline 0.0 & - & - & 1.0 & $88.00 \pm 0.50^{\text {bcde }}$ & $33.33 \pm 1.53^{\mathrm{cdef}}$ & $2.67 \pm 0.33^{i \mathrm{j}}$ & $3.33 \pm 1.92^{\mathrm{fg}}$ \\
\hline 0.0 & - & - & 2.0 & $87.00 \pm 2.08^{\text {cde }}$ & $51.62 \pm 5.44^{\mathrm{abc}}$ & $6.00 \pm 1.00^{\text {defghi }}$ & $4.33 \pm 2.50^{\operatorname{defg}}$ \\
\hline 1.0 & - & - & 0.0 & $50.67 \pm 2.96^{\mathrm{jk}}$ & $42.53 \pm 5.35^{\text {bcdef }}$ & $6.33 \pm 0.33 c^{\text {defghi }}$ & $3.67 \pm 2.12^{\mathrm{efg}}$ \\
\hline 1.0 & - & - & 1.0 & $62.54 \pm 2.24^{\mathrm{jjk}}$ & $62.70 \pm 4.32^{\mathrm{ab}}$ & $4.33 \pm 0.67^{\mathrm{hijk}}$ & $5.00 \pm 2.89^{\mathrm{bcde}}$ \\
\hline 1.0 & - & - & 2.0 & $89.34 \pm 2.29^{\mathrm{bcd}}$ & $50.31 \pm 7.48^{\mathrm{abcd}}$ & $6.00 \pm 1.53^{\text {defghi }}$ & $6.33 \pm 3.66^{\mathrm{abc}}$ \\
\hline 2.0 & - & - & 0.0 & $84.65 \pm 1.77^{\text {cde }}$ & $27.55 \pm 3.58^{\mathrm{ef}}$ & $6.67 \pm 1.20^{\text {bcdefgh }}$ & $4.33 \pm 2.50^{\operatorname{defg}}$ \\
\hline 2.0 & - & - & 1.0 & $97.67 \pm 1.76^{\mathrm{a}}$ & $64.64 \pm 3.37^{\mathrm{ab}}$ & $9.76 \pm 0.88^{\mathrm{a}}$ & $6.67 \pm 3.27^{\mathrm{ab}}$ \\
\hline 2.0 & - & - & 2.0 & $69.80 \pm 2.89^{\text {efgh }}$ & $49.52 \pm 3.95^{\text {bcde }}$ & $5.67 \pm 0.67^{\text {efghij }}$ & $5.67 \pm 3.85^{\mathrm{abcd}}$ \\
\hline- & 0.0 & 1.0 & - & $73.92 \pm 0.74^{\mathrm{efg}}$ & $48.19 \pm 2.44^{\text {bcde }}$ & $4.33 \pm 0.33^{\mathrm{hijk}}$ & $3.33 \pm 1.92^{\mathrm{fg}}$ \\
\hline- & 0.0 & 2.0 & - & $68.01 \pm 3.88^{\text {efgh }}$ & $45.26 \pm 3.09^{\mathrm{bcdef}}$ & $4.67 \pm 1.20^{\mathrm{ghijk}}$ & $4.00 \pm 2.31^{\operatorname{defg}}$ \\
\hline- & 1.0 & 0.0 & - & $77.14 \pm 0.64^{\text {def }}$ & $37.07 \pm 3.96^{\text {cdef }}$ & $6.33 \pm 0.33^{\text {cdefghi }}$ & $4.33 \pm 2.50^{\operatorname{defg}}$ \\
\hline- & 1.0 & 1.0 & - & $65.23 \pm 2.74^{\text {fghi }}$ & $43.10 \pm 3.34^{\text {bcdef }}$ & $5.00 \pm 0.58^{\text {fghijk }}$ & $4.33 \pm 2.50^{\operatorname{defg}}$ \\
\hline- & 1.0 & 2.0 & - & $93.31 \pm 2.06^{\mathrm{ab}}$ & $43.58 \pm 4.10^{\text {abcdef }}$ & $8.00 \pm 1.00^{\text {cdef }}$ & $5.67 \pm 3.27^{\mathrm{abcd}}$ \\
\hline- & 2.0 & 0.0 & - & $78.25 \pm 2.77^{\text {def }}$ & $37.55 \pm 4.21^{\text {bcdef }}$ & $7.67 \pm 0.88^{\text {cdef }}$ & $4.67 \pm 2.69^{\text {cdef }}$ \\
\hline- & 2.0 & 1.0 & - & $89.18 \pm 1.33^{\text {bcd }}$ & $34.05 \pm 4.18^{\text {cdef }}$ & $6.67 \pm 0.33^{\text {cdefgh }}$ & $4.67 \pm 2.69^{\text {cdef }}$ \\
\hline- & 2.0 & 2.0 & - & $70.79 \pm 1.68^{\text {defg }}$ & $52.80 \pm 3.46^{\mathrm{abc}}$ & $6.00 \pm 0.00^{\text {defghi }}$ & $5.33 \pm 3.08^{\text {abcde }}$ \\
\hline- & - & 1.0 & 0.0 & $81.08 \pm 3.71^{\text {edef }}$ & $33.33 \pm 2.81^{\text {cdef }}$ & $7.33 \pm 0.33^{\text {bcdef }}$ & $5.00 \pm 2.89^{a b c d e}$ \\
\hline- & - & 2.0 & 0.0 & $66.57 \pm 1.72^{\text {efgh }}$ & $53.72 \pm 3.59^{\mathrm{abc}}$ & $6.67 \pm 0.67^{\text {bcdefgh }}$ & $4.33 \pm 2.50^{\operatorname{defg}}$ \\
\hline- & - & 0.0 & 1.0 & $88.33 \pm 1.71^{\mathrm{bcd}}$ & $46.11 \pm 4.62^{\mathrm{bcd}}$ & $7.00 \pm 1.15^{\text {bcdefg }}$ & $5.67 \pm 3.27 \mathrm{abcd}$ \\
\hline- & - & 1.0 & 1.0 & $97.84 \pm 2.84^{\mathrm{a}}$ & $67.01 \pm 2.87 \mathrm{a}$ & $9.04 \pm 0.58^{\mathrm{ab}}$ & $7.00 \pm 4.04^{\mathrm{a}}$ \\
\hline- & - & 2.0 & 1.0 & $94.67 \pm 2.40^{\mathrm{ab}}$ & $54.76 \pm 3.37^{\mathrm{abc}}$ & $8.33 \pm 0.33^{\mathrm{bcd}}$ & $5.00 \pm 2.89^{\text {bcdef }}$ \\
\hline- & & 0.0 & 2.0 & $96.23 \pm 1.23^{a}$ & $24.02 \pm 2.02^{\mathrm{def}}$ & $8.33 \pm 0.33^{\mathrm{bcd}}$ & $6.33 \pm 3.66^{\mathrm{abc}}$ \\
\hline - & - & 1.0 & 2.0 & $93.69 \pm 2.79 \mathrm{ab}$ & $48.01 \pm 2.02^{\text {bcde }}$ & $8.67 \pm 0.67 \mathrm{abc}$ & $5.00 \pm 2.89^{\text {bcdef }}$ \\
\hline- & - & 2.0 & 2.0 & $78.26 \pm 2.04^{\text {def }}$ & $53.24 \pm 2.54^{\text {abcde }}$ & $6.00 \pm 0.58^{\text {defghi }}$ & $4.67 \pm 2.69^{\text {cdef }}$ \\
\hline
\end{tabular}

*Values within the column followed by the same letter are not significantly different at $\mathrm{p}=0.05$ according to DMRT; $\mathrm{n}=200$ protocorms per treatment, experiment conducted thrice maintaining five replicates. 


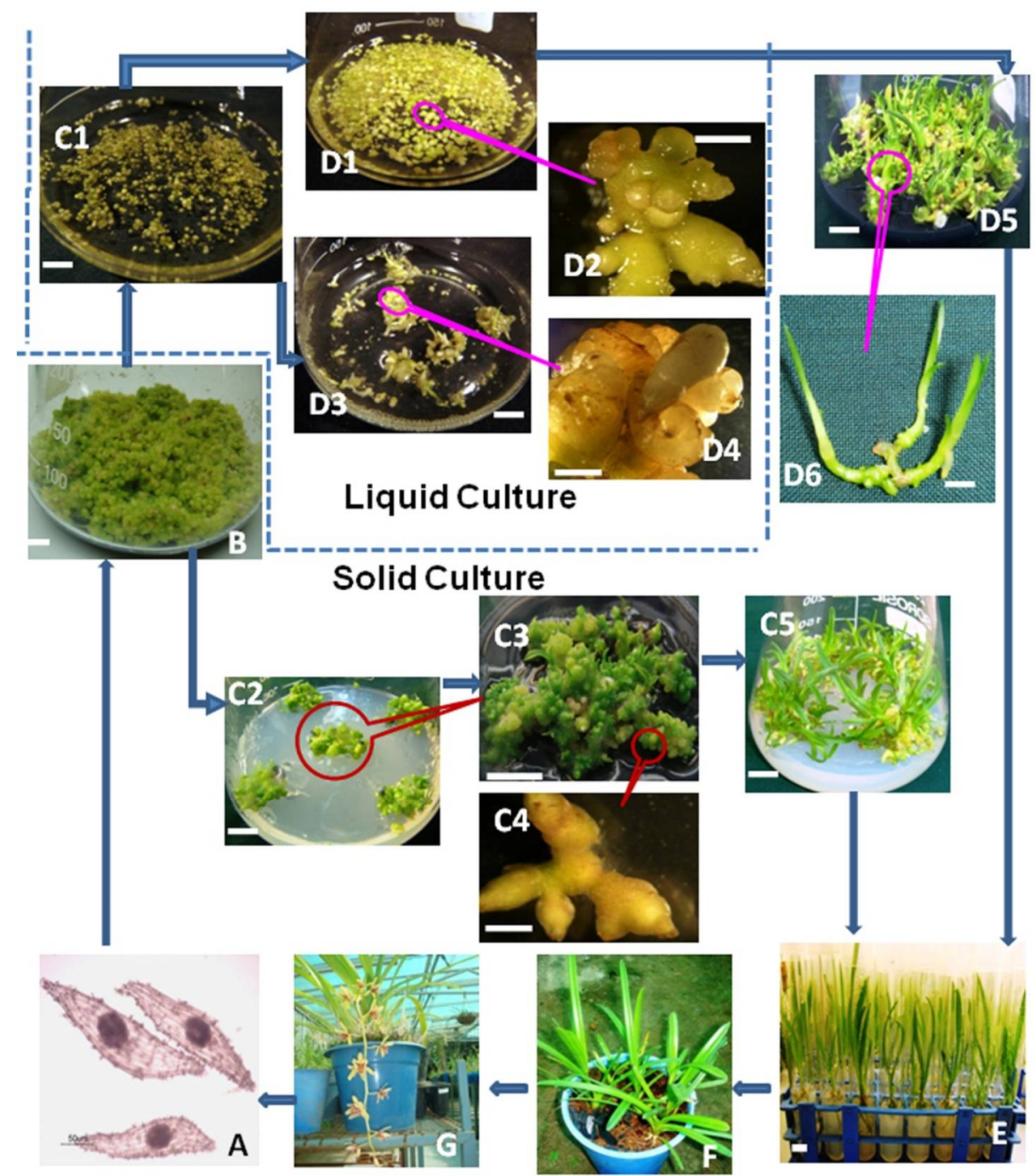

Fig 1. Regeneration of Cymbidium aloifolium from protocorms. (A) Seeds. (B) Seed originated protocorms $\left(1^{\circ}\right.$ protocorms). $\left(C_{1}\right) 1^{\circ}$ protocorms growing in liquid medium; $\left(D_{1}, D_{2}\right)$ Development of $2^{\circ}$ protocorms from $1^{\circ}$ protocorms in liquid medium. ( $\left.\mathrm{D}_{3}, \mathrm{D}_{4}\right)$ Malformation or hyperhydricity of protocorms in liquid medium after 10 weeks of culture; ( $\left.\mathrm{D}_{5}, \mathrm{D}_{6}\right)$ Induction of plantlets from proliferated $2^{\circ}$ protocorms in agar solidified medium. $\left(\mathrm{C}_{2}\right) 1^{\circ}$ protocorms growing in agar solidified medium. $\left(\mathrm{C}_{3}, \mathrm{C}_{4}\right)$ Development of $2^{\circ}$ protocorms from $1^{\circ}$ protocorms in agar solidified medium. (C5) Plantlet development from proliferated $2^{\circ}$ protocorms; (E) Development of stout root system in plantlets. (F) In vitro raised plantlets established in pots in greenhouse; $(\mathrm{G})$ Plants at flowering stage. (Bar $=5 \mathrm{~mm}$ ).

Liquid medium may have supported early and higher $2^{\circ}$ PLB formation because of the higher availability of nutrients and growth-promoting substances at the site of regeneration and because of the elimination of a correlative control imposed by other tissues and organs (Hossain et al. 2010). Vitrification or hyperhydricity of $2^{\circ}$ protocorms 
and failure of shoot regeneration in liquid medium could be correlated to tropisms or disturbances in polarity (Teixeira da Silva et al. 2006). The main benefit of direct somatic embryogenesis is that it saves time, is economical and results in propagules with uniform size and developmental performance (Hossain et al. 2010). Furthermore, within the shaking culture conditions, the growth and multiplication rate of the shoots is enhanced by forced aeration, since continuous shaking of the medium provides sufficient oxygen supply to the tissue. Moreover, liquid medium is easy to prepare and inexpensive as compared to the solid one. From the above discussion it is obvious that multiplication of protocorms in liquid medium and subsequent plantlet regeneration in agar solidified medium is advantageous, economic and less time consuming. By applying this dual phase culture system mass production of plantlets is possible in this high value medicinal orchid.

Both SBs and PLBs were induced from pseudo-stem segments of in vitro raised seedling on agar solidified medium fortified with BAP and NAA. The frequency of SBs or PLBs regeneration was greatly influenced by the concentrations and combinations of PGRs. Shoot bud differentiation was initiated directly from the dormant buds of the pseudo-stem segments within 4 - 5 weeks of culture without intervening callus phase. Shoot buds first appeared as small, green protuberances from the dormant buds that bulged into spherical structures and produced numerous axillary buds. These were proliferated profusely when transferred to fresh medium. The highest average number of shoot buds (5.80 \pm 2.59 per explant) was scored in PM medium containing BAP and NAA (1.0 mg/each). Low frequency of shoot bud induction was observed in high dosages of NAA. When BAP and NAA were supplied at higher concentration (2.0 - $5.0 \mathrm{mg} /)$, the morphogenetic pathway altered i.e., PLBs were induced instead of shoot buds. The identity of PLBs was confirmed through histological studies, wherein PLBs showed independent vascular strand. The PLBs proliferated profusely, when transferred to fresh medium and the maximum average number of PLBs $(7.20 \pm 3.22$ /explant) was recorded in $2.0 \mathrm{mg} /$ each of BAP and NAA. The above findings demonstrated that single BAP or NAA or combination of both PGRs at low concentrations influenced shoot bud regeneration, while combinations of BAP and NAA at higher concentrations (2.0 - 5.0 mg A) favoured PLBs regeneration. The shoot buds or PLBs developed in to plantlets when transferred to PGR free medium. The morphogenetic response in orchids varies depending on a number of factors such as type and source of explants, orientation of explants in the culture medium, state of the culture medium, endogenous hormone level, complex additives, culture conditions, and even culture period (Chugh et al. 2009). However, the combinations, concentrations, and the ratio of exogenous PGRs supplements are critically important (Huan et al. 2004, Hossain et al. 2013).

A number of earlier reports demonstrated that a combination of cytokinin and auxin at $2: 1$ produced shoot buds (Le et al. 1999). Appropriate combinations of cytokinins (BAP, TDZ) with NAA for somatic embryos or PLB formation was also reported (Huan et al. 2004, Teixeira da Silva et al. 2005, 2006, 2007, Hoque and Ghosh 2017). Somatic 
embryogenesis or PLB production is comparatively more efficient than organogenesis, easy to carry out and can provide large number of propagules for mass propagation within a short period of time. These systems would facilitate commercial micropropagation of orchids because they have very high regeneration potential compared to other methods.

Table 2. Rooting response in shoot buds (SBs) derived shoots of Cymbidium aloifolium.

\begin{tabular}{lcc}
\hline $\begin{array}{l}\text { Culture } \\
\text { medium }\end{array}$ & $\begin{array}{c}\text { No. of roots/shoot } \\
\text { after } 30 \text { days of culture } \\
(\text { Mean } \pm \text { SE) }\end{array}$ & $\begin{array}{c}\text { Length of roots }(\mathrm{cm}) \\
\text { after } 30 \text { days of culture } \\
(\text { Mean } \pm S E)^{*}\end{array}$ \\
\hline PM & $2.40 \pm 0.16^{\mathrm{c}}$ & $2.42 \pm 0.12^{\mathrm{c}}$ \\
$1 / 2 \mathrm{PM}$ & $2.90 \pm 0.23^{\mathrm{c}}$ & $2.76 \pm 0.13^{\mathrm{cd}}$ \\
PM+0.5 mg/ IAA & $3.70 \pm 0.33^{\mathrm{bc}}$ & $3.36 \pm 0.16^{\mathrm{b}}$ \\
PM+1.0 mg/ IAA & $4.10 \pm 0.28^{\mathrm{ab}}$ & $3.47 \pm 0.24^{\mathrm{b}}$ \\
$1 / 2 \mathrm{PM}+0.5 \mathrm{mg}$ / IAA & $5.30 \pm 0.21^{\mathrm{a}}$ & $4.44 \pm 0.16^{\mathrm{ab}}$ \\
$1 / 2 \mathrm{PM}+1.0 \mathrm{mg}$ / IAA & $4.10 \pm 0.35^{\mathrm{ab}}$ & $4.65 \pm 0.26^{\mathrm{a}}$ \\
\hline
\end{tabular}

* Mean scored from 10 replicates for each treatment. Mean value within a column followed by the same letters were not significantly different at $\mathrm{p}=0.05$.

Table 3. Rooting response in PLBs derived plantlets of Cymbidium aloifolium.

\begin{tabular}{|c|c|c|c|c|}
\hline \multirow[t]{2}{*}{ Medium } & \multicolumn{2}{|c|}{$\begin{array}{l}\text { No. of roots/plantlet } \\
\quad(\text { Mean } \pm \text { SE) }\end{array}$} & \multicolumn{2}{|c|}{$\begin{array}{l}\text { Length of roots }(\mathrm{cm}) \\
\quad(\text { mean } \pm \mathrm{SE})^{*}\end{array}$} \\
\hline & Initial & $\begin{array}{c}\text { After } 30 \text { days of } \\
\text { culture }\end{array}$ & Initial & $\begin{array}{l}\text { After } 30 \text { days of } \\
\text { culture }\end{array}$ \\
\hline PM & $1.70 \pm 0.21^{\mathrm{a}}$ & $3.40 \pm 0.27 c$ & $1.56 \pm 0.1^{\mathrm{a}}$ & $2.52 \pm 0.14^{\mathrm{d}}$ \\
\hline $1 / 2 \mathrm{PM}$ & $1.70 \pm 0.26^{\mathrm{a}}$ & $4.40 \pm 0.22^{\mathrm{ab}}$ & $1.51 \pm 0.09^{a}$ & $2.76 \pm 0.13^{\mathrm{bcd}}$ \\
\hline $\mathrm{PM}+0.5 \mathrm{mg} \Lambda \mathrm{IAA}$ & $1.80 \pm 0.20^{\mathrm{a}}$ & $4.30 \pm 0.33^{\mathrm{ab}}$ & $1.81 \pm 0.19^{a}$ & $3.42 \pm 0.17^{\mathrm{ab}}$ \\
\hline $\mathrm{PM}+1.0 \mathrm{mg} \Lambda \mathrm{IAA}$ & $1.80 \pm 0.25^{\mathrm{a}}$ & $4.50 \pm 0.27^{\mathrm{ab}}$ & $1.79 \pm 0.12^{\mathrm{a}}$ & $3.12 \pm 0.16^{\mathrm{bc}}$ \\
\hline $1 / 2 \mathrm{PM}+0.5 \mathrm{mg} / \mathrm{IAA}$ & $1.71 \pm 0.26^{\mathrm{a}}$ & $5.40 \pm 0.31^{\mathrm{a}}$ & $1.51 \pm 0.13^{\mathrm{a}}$ & $4.32 \pm 0.15^{a}$ \\
\hline
\end{tabular}

*Mean scored from 10 replicates for each treatment. Mean value within a column followed by the same letters were not significantly different at $\mathrm{p}=0.05$.

For induction of stout root system $1 / 2 \mathrm{PM}$ medium supplemented with $0.5 \mathrm{mg} / \mathrm{IAA}$ proved to be most effective for both SBs and PLBs derived plantlets (Tables 2, 3). The roots induced in $1.0 \mathrm{mg} / \mathrm{IAA}$ were very thin, long and fragile and prone to damage during ex vitro transfer. Full-strength PM medium fortified with 0.5 or $1.0 \mathrm{mg} / \mathrm{IAA}$ produced a few stunted roots per explant. Roots developed in PLBs originated plantlets were stronger and healthier than those developed in SBs. The survival rate also varied 
depending on the origin of the plantlets. The SBs originated plantlets showed $92 \%$, while PLBs originated one showed $97 \%$ survival. Induction of healthy root system in in vitro plantlets is very important for their survival in outside environment. Hossain et al. (2009, 2013) reported that deficiency of nutrition ions in the culture medium could enhance root induction in some orchid species, most probably to explore nutrient ions and water from the medium. Root development is an innate nature of plants which is controlled by endogenous level of hormones. In in vitro conditions, addition of exogenous hormone (auxins) to the medium enhances rooting response (Hossain et al. 2013). The present study suggested that combined effects of nutritional deprivation and IAA enhanced the development of stout root system in C. aloifolium.

Although extensive work has been initiated on micropropagation of many orchids yet dual phase culture of protocorms for micropropagation of orchids is limited which has several advantages. This is an efficient, reliable and reproducible protocol ever since reported for Cymbidium aloifolium. This protocol can be extended to other rare, endangered and economically important orchids for mass propagation and conservation.

\section{Acknowledgements}

Authors thank the Director, CSIR-Institute of Himalayan Bioresource Technology, Palampur, Himachal Pradesh, India for providing laboratory facilities. M. M. Hossain gratefully acknowledges the Ministry of Education, People's Republic of Bangladesh for financial support.

\section{References}

Begum AA, Tamaki M and Kako S (1994) Formation of protocorm-like bodies (PLBs) and shoot development through in vitro culture of outer tissue of Cymbidium PLB. J. Japan. Soc. Hort. Sci. 63: 663-673.

Chugh S, Guha S and Rao IU (2009) Micropropagation of orchids: A review on the potential of different explants. Sci. Hortic. 122: 507-520.

Hoque SM and Ghosh B (2017) Regeneration of cytologically stable plants through dedifferentiation, redifferentiation, and artificial seeds in Spathoglottis plicata Blume. (Orchidaceae). Hort. Plant J. 3: 199-208.

Hossain MM (2011) Therapeutic orchids: Traditional uses and recent advances - An overview. Fitoterapia 82: 102-140.

Hossain MM, Sharma M and Pathak P (2008) In vitro mass propagation of an economically important orchid, Cymbidium aloifolium (L.) Sw. J. Orchid Soc. India 22: 91-95.

Hossain MM, Sharma M and Pathak P (2009) Cost effective protocol for in vitro mass propagation of Cymbidium aloifolium (L.) Sw.- A medicinally important orchid. Engin. Life Sci. 9: 1-10.

Hossain MM, Sharma M and Pathak P (2013) In vitro propagation of Dendrobium aphyllum (Orchidaceae) - Seed germination to flowering. J. Plant Biochem. Biotech. 22: 157-167.

Hossain MM, Sharma M, Teixeira da Silva JA and Pathak P (2010) Seed germination and tissue culture of Cymbidium giganteum Wall. ex Lindl. Sci. Hortic. 123: 479-487. 
Huan LVT, Takamura T and Tanaka M (2004) Callus formation and plant regeneration from callus through somatic embryo structures in Cymbidium orchid. Plant Sci. 166: 1443-1449.

Le BV, Phuong NTH, Hong LTA and Thanh VKT (1999) High frequency shoot regeneration from Rhynchostylis gigantea (Orchidaceae) using thin cell layers. Plant Growth Regul. 28: 179-185.

Prakash O, Sood A, Sharma M and Ahuja PS (1999) Grafting of micropropagated tea (Camellia sinensis (L.) O. Kuntze) shoots on tea seedlings - A new approach for tea propagation. Plant Cell Rep. 18: 883-888.

Teisson C and Alvard D (1995) A new concept of plant in vitro cultivation liquid medium: Temporary immersion. In: Terzi M et al. (eds.) Current Issues in Plant Molecular and Cellular Biology; Current Plant Science and Biotechnology in Agriculture 22: 105-110.

Teixeira da Silva JA, Giang DTT, Chan MT, Sanjaya, Norikane A, Chai ML, Chico Ruíz J, Penna S, Granström T and Tanaka M (2007) The influence of different carbon sources, photohetero-, photoauto- and photomixotrophic conditions on protocorm-like body organogenesis and callus formation in thin cell layer culture of hybrid Cymbidium (Orchidaceae). Orchid Sci. Biotech. 1: 15-23.

Teixeira da Silva JA, Singh N and Tanaka M (2006) Priming biotic factors for optimal protocormlike body and callus induction in hybrid Cymbidium (Orchidaceae), and assessment of cytogenetic stability in regenerated plantlets. Plant Cell Tiss. Org. Cult. 84: 135-144.

Teixeira da Silva JA, Yam T, Fukai S, Nayak N and Tanaka M (2005) Establishment of optimum nutrient media for in vitro propagation of Cymbidium Sw. (Orchidaceae) using protocorm-like body segments. Prop. Ornament. Plants. 5: 129-136.

Winkelmann T, Geier T and Preil W (2006) Commercial in vitro plant production in Germany in 1985-2004. Plant Cell Tiss. Org. Cult. 86: 319-327. 